\title{
USO DE MICROCONTROLADOR NA CONSTRUÇÃO DE ESPECTRÔMETRO GAMA COM SENSOR DE NaI (TI), COM ÊNFASE EM ANALISADOR MULTICANAL, PARA APLICAÇÃO EM GEOFÍSICA NUCLEAR E AMBIENTAL
}

\author{
Nilton Silva \\ Orientador: Dr. Francisco Yukio Hiodo (IAG-USP) \\ 133 p. - Dissertação (Mestrado) - Defesa 20.05.2005
}

RESUMO. Este trabalho de instrumentação em Geofísica Nuclear teve como objetivo principal, o desenvolvimento de um protótipo de espectrômetro gama com analisador multicanal, desde 0 amplificador espectroscópico até seu firmware. 0 coração da parte digital foi um microcontrolador de 8 bits ATMEL (AT89S8252). Todos os circuitos foram feitos e montados no Laboratório de Instrumentação em Geofísica Nuclear (LIGA). 0 software do microcontrolador foi completamente desenvolvido em linguagem ANSI-C usando o compilador Small Device C Compiler (SDCC) versão 2.4.8 que é um programa distribuído sob licença tipo General Public License (GPL). Inicialmente, o microcontrolador foi usado para substituir todos os circuitos digitais de um clássico espectrômetro gama diferencial SCINTREX GAD-6. Tempos de medidas da ordem de dois dias tornaram-se possíveis e ele podia operar em ambiente não climatizado. Após esta fase, iniciou-se o desenvolvimento de um analisador multicanal (MCA) operando no modo analisador de altura de pulsos (PHA) com capacidade para 4096 canais, para uso em muitos tipos de detecção nuclear. Além disso, foi desenvolvido um sistema controle automático de ganho, para a estabilização do foto-pico através uma fonte radioativa de ${ }^{133} \mathrm{Ba}$. Os trabalhos iniciaram-se com a construção de um amplificador de ganho controlado (AGC). Este circuito de ganho controlado é muito importante no caso de sensores cintilométricos de Nal(TI), devido a sensibilidade da válvula foto-multiplicadora (PMT) à temperatura e ao envelhecimento de alguns circuitos eletrônicos do Laboratório de Geofísica Nuclear Aplicada (LGNA), onde o protótipo opera. Duas fontes de alimentação tipo no-break (uma de baixa tensão para alimentação geral e outra de alta tensão para a PMT), usando a técnica de chaveamento por modulação de largura de pulso (PWM) foram desenvolvidas para que todo 0 sistema pudesse ser alimentado com baterias de 12 Volts e, se tornasse livre de quedas da rede elétrica. A calibração em energia usando fontes padrão ${ }^{137} \mathrm{Cs}$ e ${ }^{60} \mathrm{Co}$ mostrou que 0 espectrômetro desenvolvido tem boa linearidade e baixa deriva térmica, mesmo operando na ausência de ar condicionado. Medidas de concentrações de K, U e Th foram feitas em amostras de vegetais e solo, etc.

ABSTRACT. In this work of nuclear geophysical instrumentation the main purpose was the development of a gamma-ray spectrometer prototype with multi channel analyzer, since the spectroscopic amplifier until your firmware. The heart of the digital part was an ATMEL 8 bits microcontroller (AT89S8252). All circuits were made and assembled in the Laboratory of Applied Geophysical Instrumentation (LIGA) of IAG-USP. A microcontroller software was completely developed in C ANSI language using the Small Device C Compiler version 2.4.8, that is a free software distributed under General Public License (GPL). At first, microcontroller was used to change all digital circuit of one classic SCINTREX GAD-6 differential gamma-ray spectrometer. Measurement times with order of 2 days became possible, and it could work in non climate ambient. Then, after this stage, had been started the development of a multichannel analyzer (MCA) working in pulse height analyzer mode with 4096 channels capacity, to use in many kinds of nuclear detection. Besides it, was developed an automatic gain system for photopeak stabilization, by the use of one radioactive source ( ${ }^{133} \mathrm{Ba}$ ). This automatic gain system is very important in the case of Nal(TI) scintillometric detectors, due PMT sensitivity with temperature and aging of some laboratory electronic circuits. Two power supplies with high stability, using pulse width modulation (PWM) techniques were developed, in order to all system became free of electrical line break off. One PWM power polarizes a photo multiplier tube (PMT) with high voltage and another supplies remaining developed circuits. Calibration in energy using standards sources ${ }^{137} \mathrm{Cs}$ and ${ }^{60} \mathrm{Co}$ showed that gamma detector developed has a good linearity and low thermal drift, even working in absent of air-conditioned. Concentrations measurements of $\mathrm{K}, \mathrm{U}$ and Th were made in samples of soils, vegetables, etc. 